\title{
Renewable energy sources and power-to-gas aided cogeneration for non-residential buildings
}

\author{
M. Bailera, P. Lisbona, E. Llera, B. Peña, L.M. Romeo* \\ Escuela de Ingeniería y Arquitectura. Universidad de Zaragoza, Campus Río Ebro, María \\ de Luna 3, 50018, Zaragoza, Spain,
}

\begin{abstract}
One promising technology to manage and store renewable electricity from wind or solar sources is Power to Gas (PtG). PtG combines $\mathrm{H}_{2}$ from electrolysis -run by renewable electricity- with $\mathrm{CO}_{2}$ to produce synthetic $\mathrm{CH}_{4}$. A suitable option to get the required $\mathrm{CO}_{2}$ streams is the integration with carbon capture technologies, in particular with oxyfuel combustion.

The application proposed in this study is a cogeneration system that combines PtG, oxyfuel boiler, wind energy and photovoltaic solar production to be applied in buildings. This paper describes the concept and analyses the influence of equipment dimensions varying the relative size and the proportion of the solar-wind installed power for two locations representative of North and South European countries.

Results show that higher solar and wind powers are required in the Northern region to satisfy coverage of thermal demand. It results in longer time displacement of energy storage towards cold months. Accordingly to the generation patterns of wind and solar energies, higher solar proportion results in longer energy storage periods. Therefore, solar resource is more suitable than wind power to exploit the potential of PtG technology, although the size of the overall systems increases.
\end{abstract}

\section{Keywords:}

Energy storage; Power to Gas; Oxyfuel combustion; Renewable energy sources; Near-zero emission buildings

\footnotetext{
*E-mail: luismi@unizar.es
} 


\section{Introduction}

Buildings are a strategic focus of European policies aiming to achieve a sustainable and competitive low-carbon economy. In Europe, $40 \%$ of the final energy demand and $36 \%$ of the total $\mathrm{CO}_{2}$ emitted are connected to the building sector -residential and tertiary sector together [1]. The European Commission encourages Member States to decrease this energy consumption and convert buildings from energy consumers to energy producers through retrofitting and renewable energy sources (RES). These efforts have led to a $9.52 \%$ reduction in the final energy consumption of the residential sector since 2000 , while in the tertiary sector there has been a remarkable $16.48 \%$ increase [2].

The key policy instrument towards this goal is the Energy Efficiency Directive (EED) which forces Member States to submit National Energy Efficiency Action Plans (NEEAPs) every three years and to establish a long-term strategy beyond 2020 for investing in the renovation of residential and commercial buildings [3]. Another relevant document is the Energy Performance of Building Directive (EPBD) [4], which introduces the concept of Nearly Zero Energy Buildings (NZEBs). Efforts are focused to design new buildings with low energy demand and to increase the availability of RES [5]. Considering integration of renewable energy systems in buildings, self-consumption and self-sufficiency levels can be increased by means of creating new energy demand strategies or energy storage.

From this point of view, a combination of wind power and solar photovoltaic systems represents an interesting option to provide renewable primary energy to the tertiary sector buildings under both isolated and connected operation. Solar (PV) has an average annual growth rate of around 35\% [6], the highest rate among the renewable technologies. Photovoltaic power production could reach the $25 \%$ of electrical generation in 2050 if it becomes economically competitive with the conventional power systems [7]. The wind power in Europe showed an increase of 25\% worldwide in 2017 compared to 2016 and was the power generation technology with the largest installed capacity [8]. According to WindEurope's High Scenario [9], which assumes the achievement of a 35\% EU renewable energy target and favourable market and policy conditions, wind energy would produce the equivalent to $38 \%$ of EU's power demand.

Given the fluctuating and intermittent nature of wind and solar power, short and longterm storage systems must be integrated to overcome drawbacks [10] [11] and to increase definitely the renewable share in electricity and heat consumption of the 
tertiary sector. A large number of energy concepts have been proposed for energy storage purposes namely superconducting magnetic energy storage (SMES), compressed air energy storage (CAES), ultra-capacitors, flywheel storage, pumped hydro storage, etc. Most of them have been proven in large power installation and the most suitable energy storage system depends on the final application [12][13][14]. The conventional options for energy storage, based on batteries for electricity and water tanks for thermal energy, presents serious limitations with respect to capacity for medium or long term storage. In general, applicability is limited by the specific site and the storage size [10]. According Blanco and Faaij [14] the combination of sectors and diverting the electricity to another sector can play a large role in reducing the storage size. Electrolytic hydrogen could be a potential option but changes are needed in infrastructure to deal with high hydrogen content and the suitability of salt caverns for its storage can pose limitations for this technology [15].

PtG processes, based in the conversion of renewable electricity surpluses into gaseous fuels, are promising alternatives for long-term energy storage with capacity only limited by space availability [16]. PtG technologies always include a first stage of hydrolysis through which an electrolyser converts electricity surplus and water into oxygen and hydrogen. This is the reason why in many studies the PtG viability is evaluated on the basis of available electricity [17][18]. Hydrogen is an interesting energy carrier extensively investigated to mitigate energy and environmental problems. One of the possibilities is to convert the $\mathrm{H}_{2}$ into SNG through a methanation process. It solves the drawbacks found in the usage of hydrogen as final fuel, as methane does not require any modification in current energy infrastructure nor legislation and the technology allows the connection between the electrical network and the gas network and the flexibility of the power supply system [19]. In this sense, the natural gas, which is solidly established in every economic sector, takes advantage of a consolidated technology to be used and widespread infrastructure to be transported and distributed. Given the maturity of the related technologies, reconversion efficiencies are quite higher, while costs and losses of storage and transport are even lower than for electricity itself. These advantages make natural gas a more versatile energy carrier than other alternative renewable fuels as hydrogen.

Methane can be produced by means of the well-known Sabatier reaction (Eq. 1) from $\mathrm{H}_{2}$ and $\mathrm{CO}_{2}$, previously captured or produced [20] and the natural gas produced can be 
viewed as neutral in $\mathrm{CO}_{2}$ emissions [21]. Its utilization which is suitable for building applications where energy storage systems or carriers must be as close to consumers as possible and be able to offer a rapid response [22][23].

$$
\mathrm{CO}_{2}+4 \mathrm{H}_{2} \leftrightarrow \mathrm{CH}_{4}+2 \mathrm{H}_{2} \mathrm{O} \quad \Delta \mathrm{H}_{298 \mathrm{~K}}=-164.9 \mathrm{~kJ} / \mathrm{mol}
$$

The global exothermic mechanism consists of two consecutive reactions, the endothermic water-gas shift (Eq. 2) and the methanation of the $\mathrm{CO}$ (Eq. 3).

$$
\begin{array}{ll}
\mathrm{CO}_{2}+\mathrm{H}_{2} \leftrightarrow \mathrm{CO}+\mathrm{H}_{2} \mathrm{O} & \Delta \mathrm{H}_{298 \mathrm{~K}}=+41.5 \mathrm{~kJ} / \mathrm{mol} \\
\mathrm{CO}+3 \mathrm{H}_{2} \leftrightarrow \mathrm{CH}_{4}+\mathrm{H}_{2} \mathrm{O} & \Delta \mathrm{H}_{298 \mathrm{~K}}=-206.4 \mathrm{~kJ} / \mathrm{mol}
\end{array}
$$

As the first reaction (Eq. 2) requires the availability of $\mathrm{CO}_{2}$ and several sources of $\mathrm{CO}_{2}$ have been previously pointed out [24][25], the present work proposes a hybrid system that combines PtG technology (i.e. electrolysis and methanation) with an oxyfuel boiler where the methane is burnt to produce heat and $\mathrm{CO}_{2}$. This novel concept [26] has been recently evaluated in district heating sector [27], power production [28], and in an electrochemical industry [29] with promising results from the energy consumption and environmental points of view.

The present work investigates the technical feasibility of the Wind-PV-PtG-oxyfuel boiler system for cogeneration in the tertiary sector under scenarios of different ratios of wind-PV power installed. The aim of this paper is to explore the possibilities of an energy system that integrates production and storage closed to the consumer and whose electricity and thermal demand have to be instantaneously covered. Sports centres are taken as application case of the tertiary sector given their high energy consumption and large available area for installing wind urban turbines and photovoltaic panels.

\section{RES production and energy consumption profiles in sports buildings}

The combination of wind power, photovoltaics energy sources and Power to Gas in non-residential buildings could allow supplying with only renewable electricity at the same time that surpluses are converted into methane. Thus, facilities with moderate heating demands that use natural gas boilers are potential users of this renewable cogeneration system (e.g., heated indoor pools, shopping malls, resorts). 
Sports centres are taken as application case of the tertiary sector buildings given their high energy consumption and large available area for installing wind urban turbines and photovoltaic panels. Sports centres are equipped with complex technology which causes considerable electricity consumption mainly for ventilation and electrical engineering. Furthermore, some centres are also equipped with additional energy-intensive installations such as swimming pools, saunas, solariums, wellness area, etc. resulting in a large share of the energy consumption not only for water heating but also for space heating.

Climate conditions present a strong influence on the energy demand pattern and the electricity production profiles of this kind of facilities. For this reason, the geographical locations for the case studies to be compared in the present research have been carefully selected to be representative of Southern and Northern Europe in terms of renewable power generation. According to a preliminary study of climate conditions of different locations, Zaragoza (Spain) and Landskrona (Sweden) have been selected.

Regarding solar resource, daily and seasonal data were extracted from PVGIS tool [30] and compared to that of five different cities for each region: Seville, Roma, Athena, Toulouse and Pristina in Southern Europe and Stockholm, Oslo, Helsinki, Riga and Copenhagen in the Northern Europe. Among the Southern cities, Zaragoza exhibits the smallest deviation with respect to the average value of global annual irradiation (2\%) with the smallest maximum deviation (5\% in August). For the Northern cities, Landskrona and Helsinki exhibit a similar behaviour with the smallest deviation to the average global annual irradiation (1\%) and a maximum deviation of around $30 \%$ in December.

As for wind power generation, given the very high variability of wind resource at very small geographic scale, total hourly production of wind power for the whole previously selected countries, Spain and Sweden [31][32], has been used to establish wind production profiles after an appropriate scaling down to the size of the analysed energy scenarios. Since the data are aggregated over an important extension in Southern and Northern Europe, Zaragoza (Spain) and Landskrona (Sweden) can be considered representative locations of the extreme cases in Europe in terms of renewable generation patterns under South and North European climate conditions, respectively. Finally, monthly energy consumption data were obtained from two energy audits in sport centers of both locations with a typical commercial offer of South and North European 
regions [33][34][35]. The Swedish case was part of the Green Hub Landskrona project about public facilities: the only one city's ice rink with audience capacity of 1400 people and the main city's public swimming pool, which includes a small outdoor pool and different water play areas. Such data were the starting point to establish the different scenarios analysed and compared in the paper.

\subsection{Electrical and thermal demand}

In these facilities, most important electrical demands come from dehumidifiers, lighting, and pumps, followed by air conditioners, appliances and computers. The typical total electric consumption, $\mathrm{E}_{\mathrm{d}}$, may span in the range $300-1000 \mathrm{MWh} / \mathrm{y}$ depending on the size of the centre $[33,36]$.

The influence of the ratio of thermal/electricity demand, taking constant the maximum electricity production calculated with the roof area, was analysed in a previous paper [37]. This study is borne out from a thorough decision-making methodology developed by the authors. The cited work stablished the calculation and discrimination procedures for 35 potential cases that may take place while managing this kind of hybrid facilities. Demand (thermal + electricity) is used as an input and the work includes and analysis of different productions necessities without the limitation imposed by the available roof area $(\mathrm{PV})$ or land (wind power).

In the Spanish case, the pattern shows a peak of consumption in June and July due to the cooling necessities, a stable period between October and March, and a drop for April and May (Fig. 1). Contrarily, the Swedish case presents a decrease in demand during August, due to the temporary close of some of the facilities. The hourly electricity demand is simplified by considering full load when the building is open, and only the dehumidifier's consumption when it is closed, which is $37 \%$ of the daily consumption for the Spanish case and $18 \%$ of the daily consumption for the Swedish case.

Annual thermal demands, $\mathrm{Q}_{\mathrm{d}}$, in sports buildings are mainly due to indoor pools heating purposes, as well as domestic hot water production and space heating in the building. Typical consumptions widely vary depending on the location and type of facilities (200 - $1000 \mathrm{MWh} / \mathrm{y}$ ). Demand is distributed along the year following the data shown in an energy audit of a sport centre in Zaragoza [33] and the Green Hub Landskrona project [35]. The load curve (Fig. 1) clearly shows a seasonal behaviour where consumption increases during the coolest months, in both countries. The hourly demand is simplified 
by considering full load when the centre is open, and only the pool heating consumption when it is closed, which represents the $64 \%$ of daily consumption in the Spanish case. A more detailed pattern for the pool heating is assumed for the Swedish case, which considers a variable share of the daily thermal consumption depending on the month of the year (e.g., 19\% for February and 93\% in August).
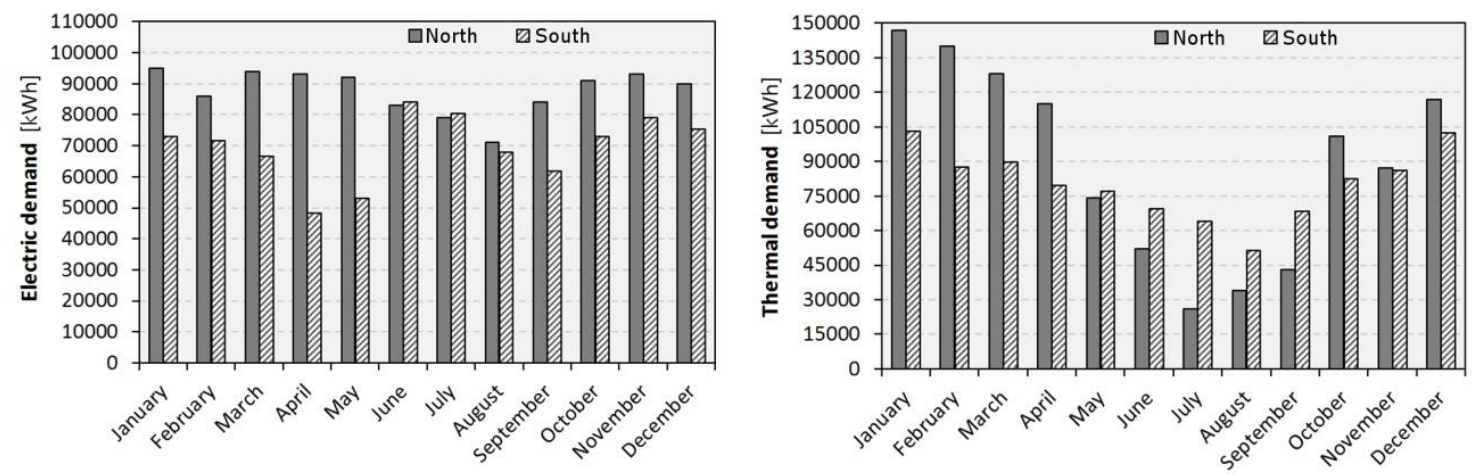

Fig. 1. Monthly electric and thermal demand for selected locations.

\subsection{PV and wind power production}

Once the electricity and thermal demand are described, the scenarios of renewable electricity production are also defined. Four scenarios of renewable electricity production are considered, corresponding to productions of 1.50, 1.75, 2.00 and 2.25 times the annual electricity demand of the sports centres $(1249-1873 \mathrm{MWh} / \mathrm{y}$ of renewable production in Spain, and 1576 - $2365 \mathrm{MWh} / \mathrm{y}$ in Sweden). Moreover, for each of these scenarios a parametric analysis is performed by considering that the renewable electricity is produced through different combinations of $\mathrm{PV}$ and wind power (100\%PV-0\%Wind, 75\%PV-25\%Wind, 50\%PV-50\%Wind, 25\%PV-75\%Wind and 0\% PV-100\%Wind). It makes twenty possible scenarios.

The daily and seasonal variability of photovoltaic production have been characterized for two different climate conditions. Solar data of hourly global irradiance $\left(\mathrm{W} / \mathrm{m}^{2}\right)$ and electricity production from $1 \mathrm{~kW}$ PV panels have been obtained for Zaragoza (Spain) and Landskrona (Sweden) using the PVGIS Tool (Photovoltaic Geographical Information System) [30], and considering an average day for every month. Then, the installed capacity is increased up to reaching the values of annual electricity production assumed for PV technology in the proposed scenarios of renewable production (e.g., 
$223 \mathrm{~kW}$ of PV are required in Spain when the renewable production is assumed 1.5 times greater than the electricity demand and the share of renewable technologies is $25 \% \mathrm{PV}-75 \% \mathrm{Wind}$; for the Swedish case, this value increases to $472 \mathrm{~kW}$ of PV installed power).

Similarly, the available wind resource is quantified in a daily and seasonal basis for both geographical locations, Zaragoza (Spain) [31] and Landskrona (Sweden) [32]. Average hourly values of electricity production $(\mathrm{kWh})$ for a typical day of each month of the year 2017 have been considered. As these values correspond to the total installed capacity of wind power in each country, the data is scaled down for the sports centres in order to have the amount of electricity production assumed in the energy scenarios (e.g. $447 \mathrm{~kW}$ of wind power are required in Spain when the renewable production is assumed 1.5 times greater than the electricity demand and the share of renewable technologies is $25 \% \mathrm{PV}-75 \% \mathrm{Wind}$; for the Swedish case, this value is $465 \mathrm{~kW})$..

Thus, solar and wind production profiles are scaled down to the dimension of the proposed energy scenarios and parametric analyses. The data of the different installed capacities are later presented in the results section.

\section{Wind-PV-PtG-Oxyfuel boiler system}

The hybrid system proposed in this study to cover the energy requirements of a standard sport building includes a combination of wind turbines, photovoltaic panels, $\mathrm{PtG}$ and an oxyfuel boiler. The hybridization of PtG with oxyfuel boiler produces a double positive synergy as presented in Fig. 2. On the one hand, oxyfuel boiler acts as a source of concentrated $\mathrm{CO}_{2}$ for methanation and, on the other hand, it takes advantage from the $\mathrm{O}_{2}$ by-produced during the electrolysis stage. Since this oxygen serves as comburent in the boiler, the use of an air separation unit (ASU) to provide the stream of pure oxygen would be in some cases unnecessary [26].

With the aim of being exhaustive, a wide variety of operation scenarios are investigated for the Wind-PV-PtG-Oxyfuel system. Some of them lead to a low coverage of the thermal supply. In such cases, it will be assumed that sports buildings maintain their conventional air-fired boilers to support the thermal demand. Nevertheless, it will also be quantified the power consumption of the required ASU for a hypothetic oxyfuel 
boiler sized to cover the whole demand, since $\mathrm{O}_{2}$ from the electrolysis would be insufficient in that cases.

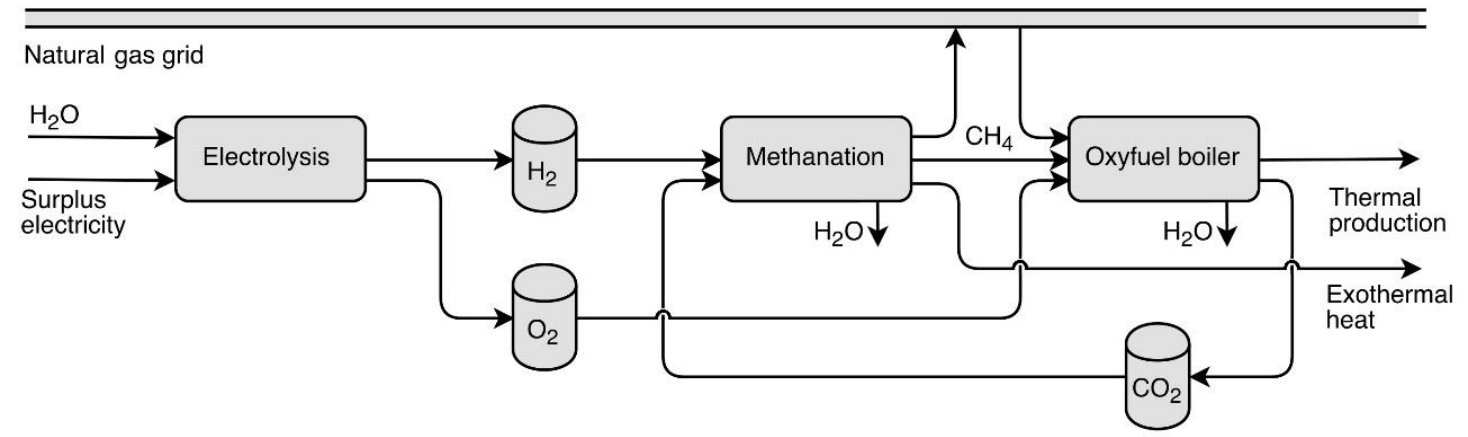

Fig. 2. PtG-Oxyfuel boiler integration scheme

Excess electricity from wind turbines and PV panels will be chemically stored through the Power to Gas subsystem, firstly in the form of hydrogen and finally in methane. The boiler will partly cover the thermal demand of the analysed facilities together with the heat released during the exothermal methanation, which is also directly integrated as a useful output. Whenever the methane production exceeds thermal demand, it will be injected into the gas grid to be stored and to displace its consumption to other periods or seasons. When necessary, the natural gas recovered from the grid will be consumed in the oxyfuel boiler whenever possible; otherwise, it will feed the air-fired boiler.

Additionally, buffers are required to manage the $\mathrm{H}_{2}, \mathrm{O}_{2}$ and $\mathrm{CO}_{2}$ surpluses and deficiencies. Hydrogen will be a surplus when it exceeds the amount treated by the methanation plant, and it will be a lack when it is not enough to convert the $\mathrm{CO}_{2}$ from the oxyfuel boiler. In the case of oxygen, it will be an excess when not all the produced methane is consumed, and a lack when synthetic natural gas is recovered from the network. Carbon dioxide will be a surplus when consumed methane overcomes the produced methane, and it will be a shortage when methanation is not operated at full load although there is hydrogen enough to do so.

The PtG-oxyfuel boiler sub-system has been modelled in Aspen Plus ${ }^{\circledR}$ under chemical equilibrium and steady state operation, in order to evaluate the efficiency of the system. Electrolyzer unit splits water in pure oxygen and a mixture of hydrogen and water. Water conversion in this device achieves $99.9 \%$, and the electrical consumption is set at $4.2 \mathrm{kWh} / \mathrm{Nm}^{3} \mathrm{H}_{2}$ [38]. These operation conditions lead to an electrolysis efficiency of $70.0 \%$ (LHV basis). Hence, it is taken into account the fact that the electrolyser will 
work mostly below the nominal load and that the efficiency increases at partial loads [39].

Combustion of SNG fuel in the boiler is supposed under conditions of chemical equilibrium with comburent flow. The sensible heat of the combustion gas is transferred to produce hot water. A final flue gas temperature of $270{ }^{\circ} \mathrm{C}$ is achieved, which is used to preheat the recycled flue gas up to $180{ }^{\circ} \mathrm{C}$. The exhaust gas stream is partially recycled into the boiler (79\%), and partially feeds the methanation system $(21 \%)$. Therefore, the comburent in the oxyfuel boiler is composed by $\mathrm{O}_{2}$ from electrolyser plus partially-dried flue gas.

Methanation stage is composed of two isothermal reactors at 10 bar and $350{ }^{\circ} \mathrm{C}$, with an intermediate water condenser. The final synthetic natural gas achieves a $95 \%$ of methane content. The thermal efficiency of the methanation stage is $81.1 \%$ (energy content ratio between $\mathrm{SNG}$ and $\mathrm{H}_{2}$ ), and the efficiency of the boiler is $85 \%$. A full description can be found in previous works [27] [40]. Moreover, the heat released during methanation is quantified as a useful output of the system and integrated in the model to produce domestic hot water (a $20 \%$ loss of the available heat is assumed).

\section{Results and discussion}

The consumption profiles previously described have been taken for typical facilities in Spain and Sweden, so the results of the study refer to both Southern and Northern Europe scenarios. Results quantify the electricity demand that can be replaced with photovoltaic and wind production and the existing surplus electricity for every scenario. According with the results presented previously [37]. Power to Gas facility is properly sized to maximize the amount of surplus energy that is processed at nominal load in each case. Then, it is calculated the coverage of thermal demand supplied with the energy stored in form of methane.

Main results are shown in tables 1 and 2. Discussion has been divided into three main blocks which includes; (i) Equipment sizing, (ii) Energy flows and RES consumption coverage of the facilities and (iii) Energy storage potential.

Table 1. Main results for the system located in Zaragoza (Spain) 


\subsection{Equipment sizing}

The information in this subsection includes the corresponding size and hours of operation of the electrolyser which will store the surplus electricity from RES, the annual energy consumption and required sizing of the air separation unit, the corresponding size of the oxyfuel boiler and the size and number of hours of operation of the methanizer.

\section{Electrolyser}

The electrolyser power is dimensioned maximizing the hours of operation at nominal load by means of the load duration curve [37]. It manages the electricity surplus from renewable sources and stores the maximum possible amount of energy. The electrolyser installed capacity is presented in Figure 3 for different combinations of wind and photovoltaic powers and excess ratios (cases $(a)$ to $(d)$ ). The full line represents the results obtained for the South Europe location and the dotted line illustrates the results for the North Europe one.

The lowest amounts of stored electricity are presented when electricity is mostly generated by wind power. Thus, electrolyser capacity requirements will also be minima for these situations. When produced electricity from wind power ranges between 50$100 \%$, the electricity capacity of electrolyser will range between 60 and $200 \mathrm{~kW}$ (around $100 \mathrm{~kW}$ for most cases) with higher number of operating hours (from $3500 \mathrm{up}$ to 7600 hours). The combination of lower investment costs related to limited electrolyser sizes and larger numbers of operating hours will enhance the economic feasibility of this equipment under these scenarios. 

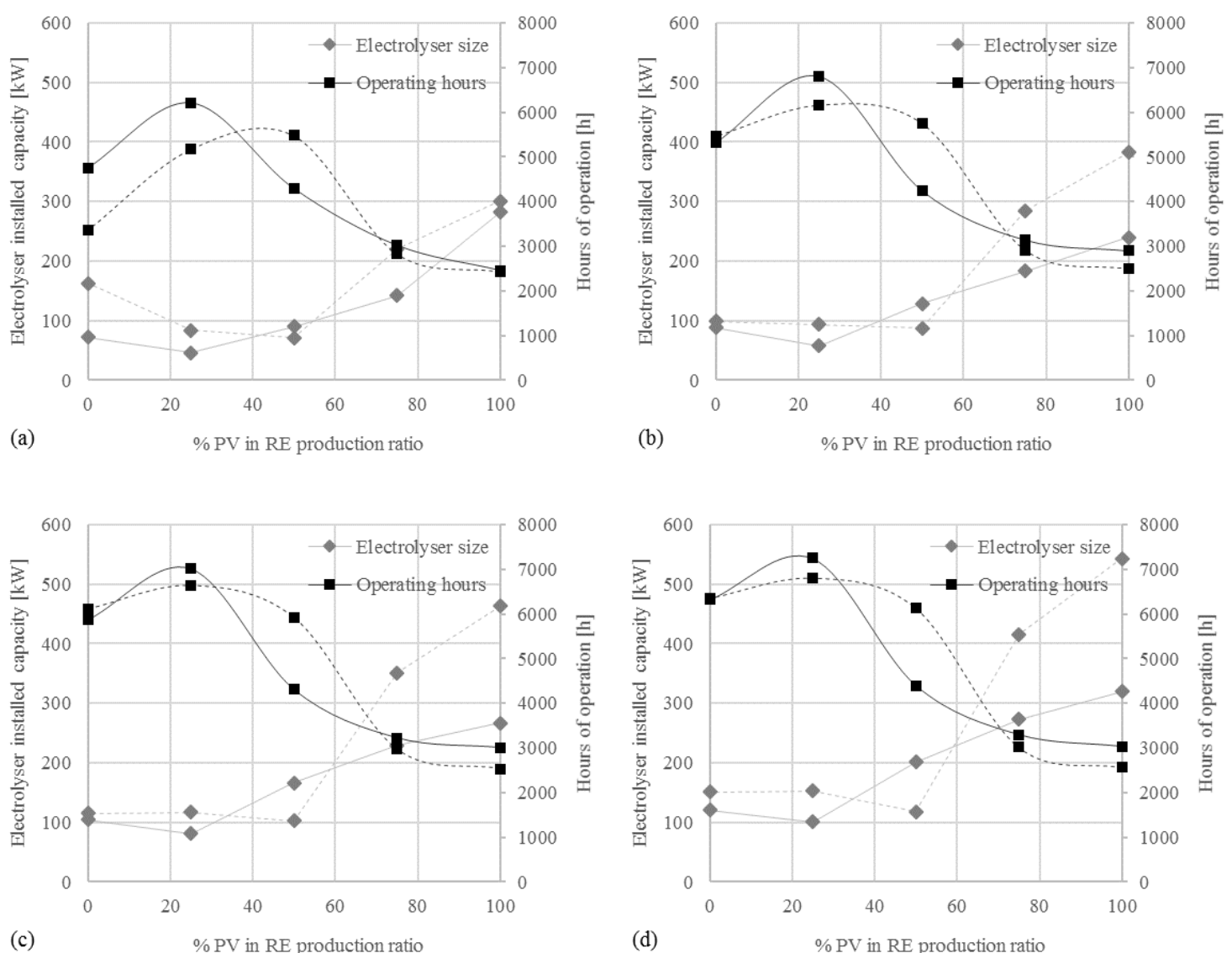

Fig. 3. Electrolyser installed capacity and hours of operation for different $\left.E_{P V} / E_{R E S}: a\right)$ $E_{R E S} / E_{d}=1,5$; b) $\left.\left.E_{R E S} / E_{d}=1,75 ; c\right) E_{R E S} / E_{d}=2,0 ; d\right) E_{R E S} / E_{d}=2,25$. Full line represents South Europe results and Dotted line represents North Europe results.

\section{Methanation system}

The size of the methanation system is set according to the most limiting factor among the nominal $\mathrm{H}_{2}$ production and the maximum hourly thermal demand. If the heat production that can be obtained from the nominal hydrogen generation (SNG combustion plus exothermal heat) is lower than the maximum thermal demand, then the methanation nominal input will be sized equal to the nominal $\mathrm{H}_{2}$ production. Besides, the nominal input of the oxyfuel boiler will be the nominal production of SNG (i.e., the size of a subsystem is set by the preceding one). Conversely, if the nominal hydrogen production allows providing more thermal energy than the maximum thermal demand, the methanation will be scaled down to match producible heat and maximum demand. Otherwise, the methanation system would be oversized. In that case, the air-fired boiler loses its relevance and the oxyfuel boiler should be sized to fulfil maximum demand 
even when exothermal heat integration is not available (i.e., when SNG is recovered from the gas network).

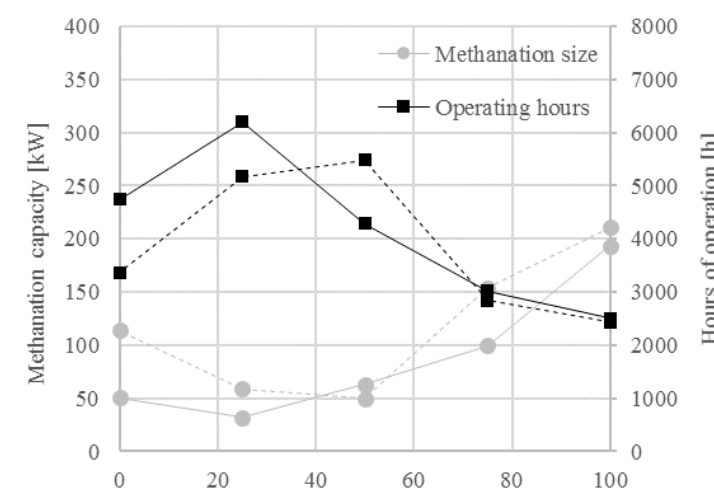

(a)

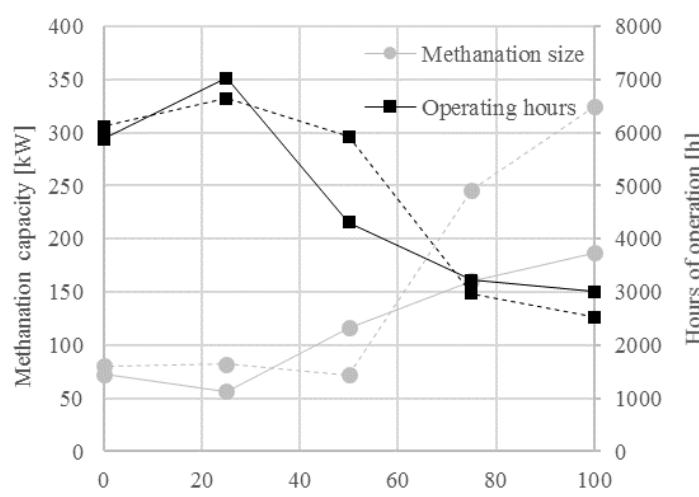

(c)

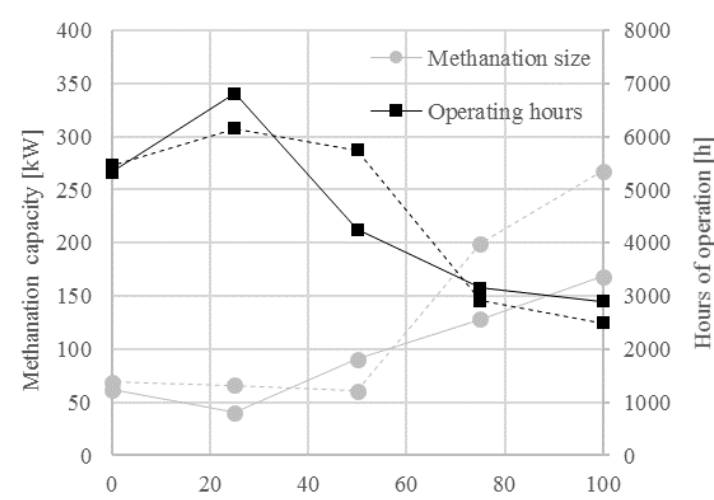

(b)

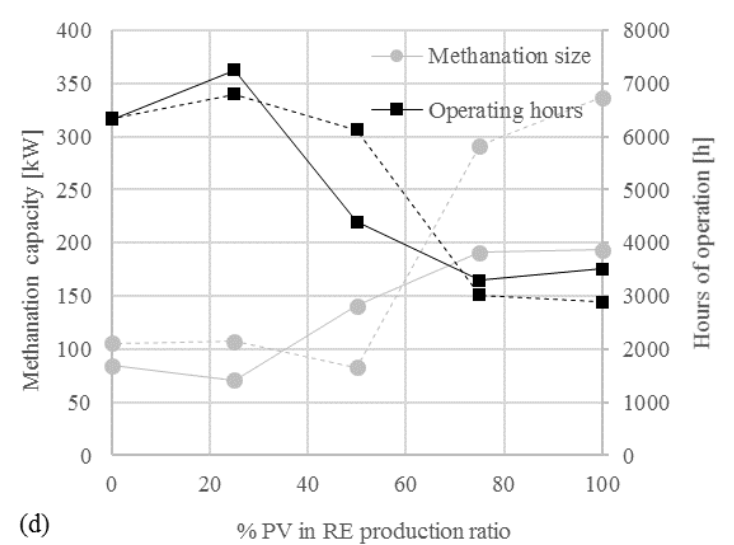

Fig. 4. Methanation system size and hours of operation for different $E_{P V} / E_{R E S}:$ a) $E_{R E S}$ $E_{d}=1,5$; b) $E_{R E S} / E_{d}=1,75$; c) $\left.E_{R E S} / E_{d}=2,0 ; d\right) E_{R E S} / E_{d}=2,25$. Full line represents South Europe results and Dotted line represents North Europe results.

As illustrated in Figure 4, methanation size ranges between 50 and $150 \mathrm{~kW}$ for those scenarios with lower photovoltaic power installed capacities (between 0-50\% of photovoltaic power in the generation mix). The number of operating hours of the methanation facility under these scenarios varies from 4200 and 7200 hours and between 6000 and 7200 for the most favourable cases which may lead to economic feasibility of the equipment. When photovoltaic power produces between 75 and 100\% of the RES electricity in the system, the number of operating hours decays below 3500 hours. 


\section{$\mathrm{H}_{2}$ storage tank}

Each scenario will require a hydrogen buffer tank of different size (Figure 5). As already mentioned, low percentages of photovoltaic power in the generation mix will lead to a better match between electric demand and production profiles. Therefore, storage of electricity and consequent storage of hydrogen will be smaller for those situations.

For wind power generation share between 50 and $100 \%$ the required size of hydrogen storage tank will be between 4 and $20 \mathrm{~m}^{3}$ (NTP). Under most of the studied scenarios, it will present a value around $10 \mathrm{~m}^{3}(\mathrm{NTP})$.

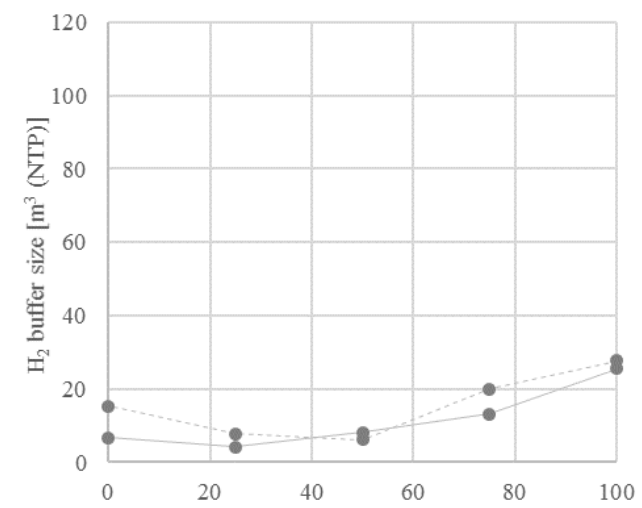

(a)

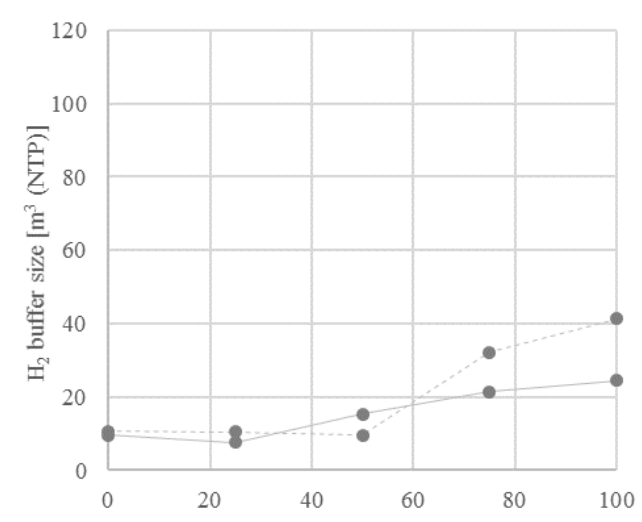

(c)

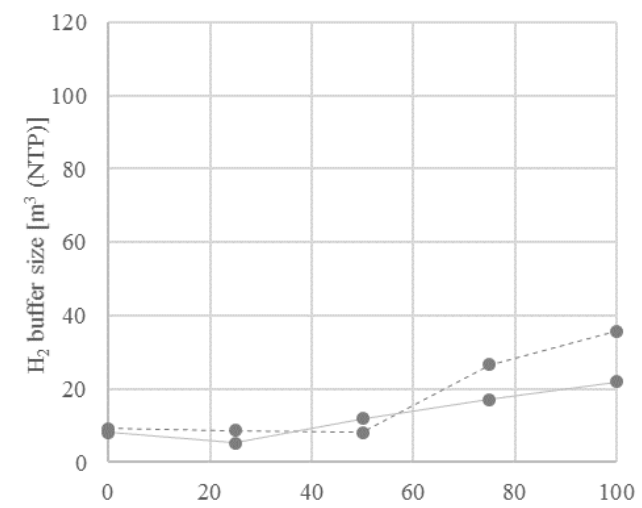

(b) $\% \mathrm{PV}$ in $\mathrm{RE}$ production ratio

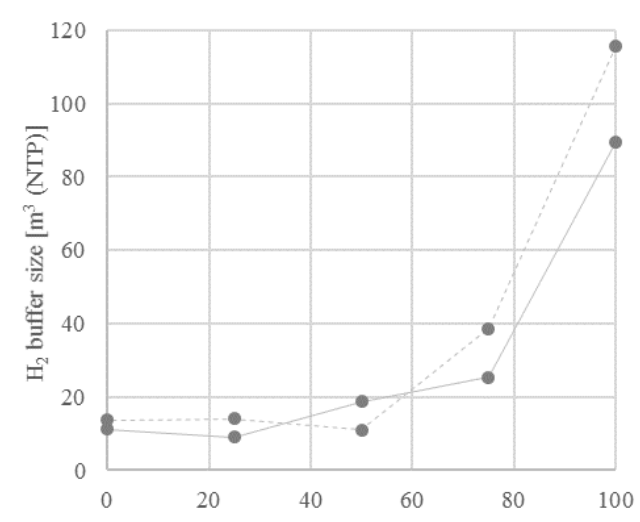

(d) $\% \mathrm{PV}$ in $\mathrm{RE}$ production ratio

Fig. 5. Hydrogen buffer size for different $E_{P V} / E_{R E S}$ : a) $\left.E_{R E S} / E_{d}=1,5 ; b\right) E_{R E S} / E_{d}=1,75$;

c) $\left.E_{R E S} / E_{d}=2,0 ; d\right) E_{R E S} / E_{d}=2,25$.

Regarding the buffer demand, the same trend is observed for the three gases - hydrogen, oxygen and carbon dioxide. That scenario which allows methanation reactors to operate the largest number of hours will be much more demanding of buffering capacity. Thus, scenario with excess ratio of 2,25 and $100 \%$ electric generation from photovoltaic 
power is found to demand buffer capacities extremely higher (one order of magnitude above) when compared with the rest of scenarios. These equipment will increase the investments costs of the last scenario and, moreover, will demand the availability of free space to build the gasometers in the nearby of the sport centre which will not probably exist downtown in the city. On the other hand, as Figure 12 shows, this scenario allows an energy storage displacement of more than 6000 hours (250 days) and the excess energy from the summer can be used in winter. This is an advantage of this kind of systems in comparison with other short-term energy storage alternatives.

\section{ASU and oxyfuel boiler}

The oxyfuel boiler is sized considering the oxygen availability provided from the electrolyser which store the RES surplus electricity. Once the oxyfuel boiler is sized the coverage of thermal demand from this source in the sport facilities should be assessed to determine whether another air-fired boiler is required in the system or not. This oxyfuel boiler is necessary to produce $\mathrm{CO}_{2}$ for the methanation and its size has to be large enough to avoid the necessity of an air-fired boiler in parallel.

As shown in Figure 6, oxyfuel boiler size will range between 30 and $120 \mathrm{~kW}$ when electricity from RES is mostly provided by wind power (between $50-100 \%$ of wind power). The lower storage capacity of the overall system under these scenarios limits the availability of oxygen to provide the comburent to the oxyfuel boiler.

When photovoltaic power provide the larger share of electricity generated in the system (75-100\% of photovoltaic power) and storage capacity is increased, the oxyfuel boiler is varied from 100 to $330 \mathrm{~kW}$ and the thermal demand of the sport facilities will be covered by this equipment in a much higher percentage.

In case the whole thermal demand of the sport facilities is to be covered with the energy provided by the oxyfuel system, an air separation unit will be required to provide the amount of comburent not generated in the electrolyser. The size of the required ASU, considering a specific energy consumption of $190 \mathrm{kWh} / \mathrm{tO}_{2}$ [41], will be $12,6 \mathrm{~kW}$ for the South Europe facility and 22,0 kW for the North Europe facility. The minimum costs associated to the air separation unit will be found in scenarios with high participation of photovoltaic power generation with the lowest investment cost - smallest size of the ASU - and the lowest yearly electricity consumption required to run ASU operation. 


\subsection{Energy flows and RES-consumption coverage}

The results presented in this subsection analyses the energy flows of the sport facilities and include the required renewable energy installed power (both photovoltaic and wind), the electricity surplus over demanded electricity and the electricity available for storage.

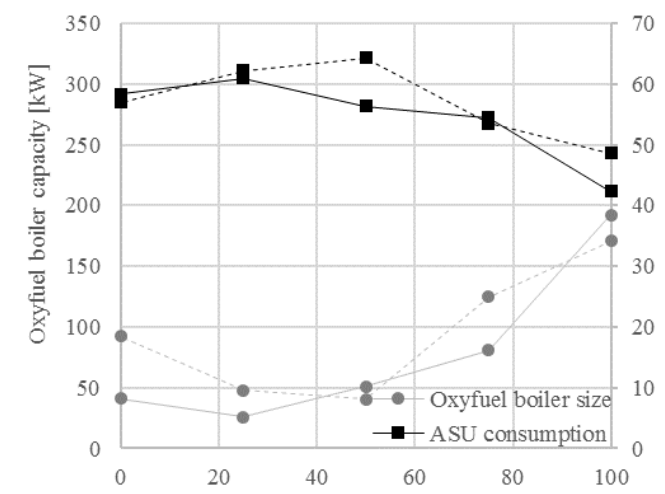

(a)

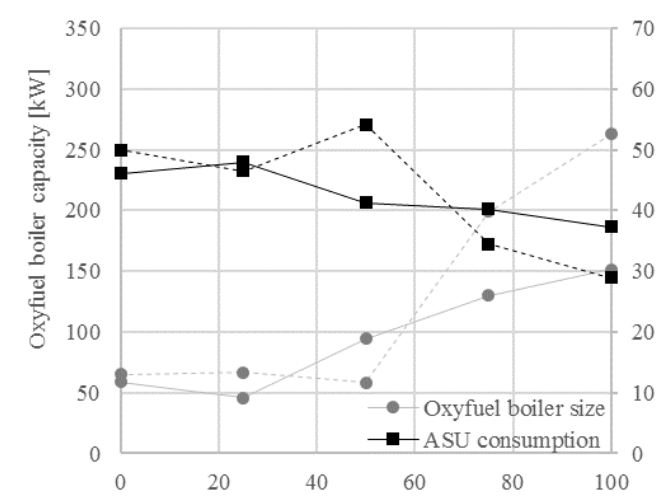

(c)

$\% \mathrm{PV}$ in $\mathrm{RE}$ production ratio

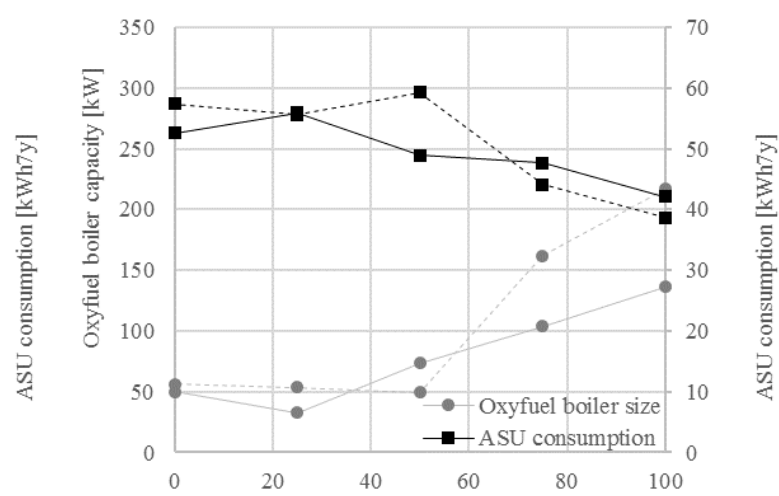

(b)

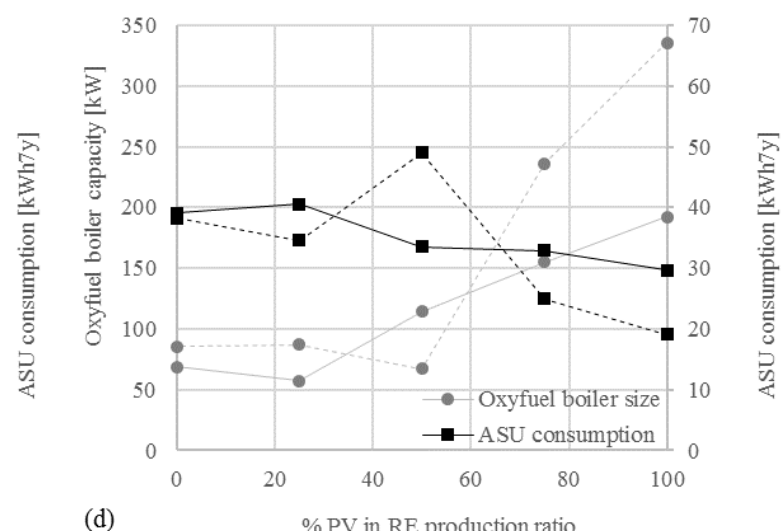

(d)

Fig. 6. Oxyfuel boiler capacity and ASU consumption (oxyfuel operation) for different $E_{P V} / E_{R E S}:$ a) $E_{R E S} / E_{d}=1,5$; b) $\left.\left.E_{R E S} / E_{d}=1,75 ; c\right) E_{R E S} / E_{d}=2,0 ; d\right) E_{R E S} / E_{d}=2,25$. Full line represents South Europe results and Dotted line represents North Europe results.

\section{Installed capacity and RES electric demand coverage}

As stated in Figure 1, the annual electricity demand amounts to 836,6 MWh and 1051,0 MWh for the South Europe case and the North Europe case respectively. These values $\left(E_{d}\right)$ together with the $E_{R E S} / E_{d}$ excess ratio $\left(E_{R E S} / E_{d}\right.$ values between 1,5 and 2,25) will define four electricity surplus scenarios (annual RES electricity surplus of 50\%, 75\%, $100 \%$ or $125 \%$ over the annual electricity demand) which set the annual renewable production $\left(E_{R E S}\right)$. 
The installed capacity of photovoltaic and wind power to provide a given RES electricity surplus have been calculated for different combinations of renewable sources production varying from $0 \%$ to $100 \%$ of photovoltaic power.

Required RES installed capacity varies from 595 to $895 \mathrm{~kW}$ (SE case) and from 621 to $931 \mathrm{~kW}$ (NE case) when only wind power is implemented in the facility. When the electricity is provided by photovoltaic power, the distribution of hours of operation leads to much higher required PV installed capacities; from 892 to $1338 \mathrm{~kW}$ (SE case) and from 1890 to $2835 \mathrm{~kW}$ (NE case). From the point of view of the consumption of electricity from renewable sources, the lower share of photovoltaic power in electricity generation, the higher electricity demand coverage. Obtained results are quite similar for all the studied scenarios and the RES-consumption share varies between 55 to $99 \%$. Surplus electricity from RES over $100 \%$ and photovoltaic participation in RES generation under 50\% lead to the most advantageous situations to ensure the electric coverage from RES.

Figure 7 illustrates the obtained results for these cases under two different patterns of electric and thermal demands in sport facilities: South Europe case (SE - full line) and North Europe case (NE - dotted line).

\section{RES electricity surplus and storage}

Once the different scenarios have been defined, it is possible to estimate the percentage of the produced renewable electricity over the total electric demand of the sport facilities. These values of surplus electricity ranges from near $40 \%$ to $75 \%$ for the scenario with the lowest electricity surplus to the scenario (Fig.8(a)) with highest electricity surplus (Fig. $8(d)$ ), respectively. It is worth to notice that the higher wind power installed in the combined system, the lower electricity surplus. This reduction is due to the more similar pattern of the combined RES electricity generation (wind and photovoltaic power) to the electricity demand pattern of the studied facilities. Opposite to the increasing trend of percentage of stored electricity with photovoltaic increasing percentage in the generation mix $\left(E_{P V} / E_{R E S}\right)$ and with excess ratio $\left(E_{R E S} / E_{d}\right)$, the profiles of stored electricity does not follow a clear trend. This value is controlled by the specific demand of the sport facility and the strong influence of the location (North vs. South) is clearly noticed in Figure 8. 
The share of surplus electricity which is stored in the electrolyser ranges between 50 and $83 \%$ for the North Europe facility and between 60 and $90 \%$ for the South Europe sport facility.
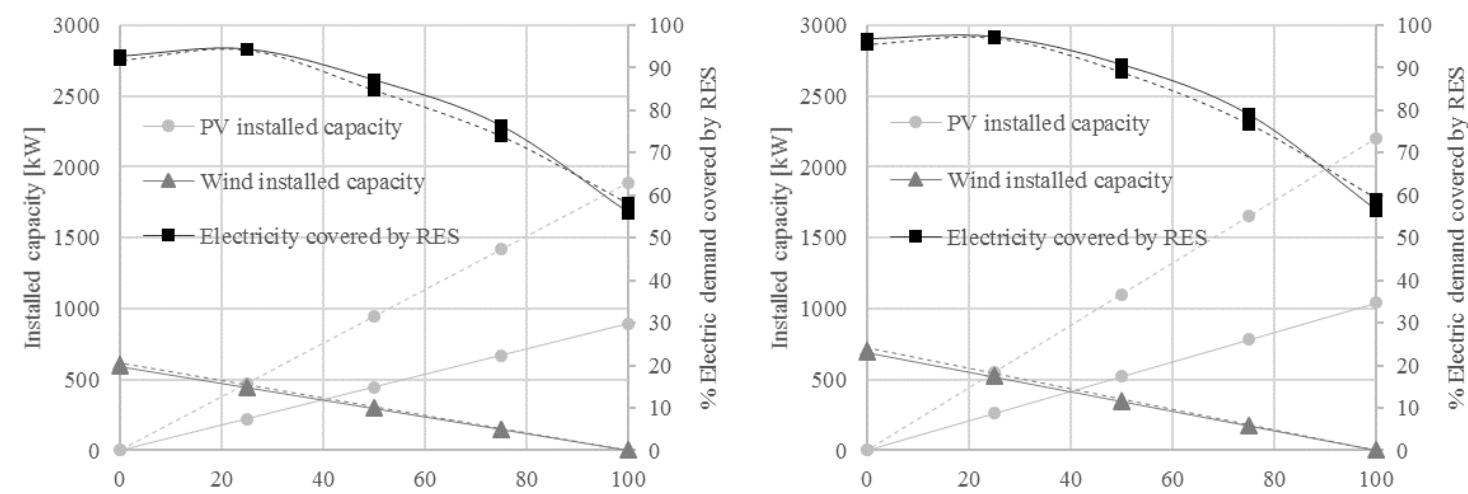

(a)
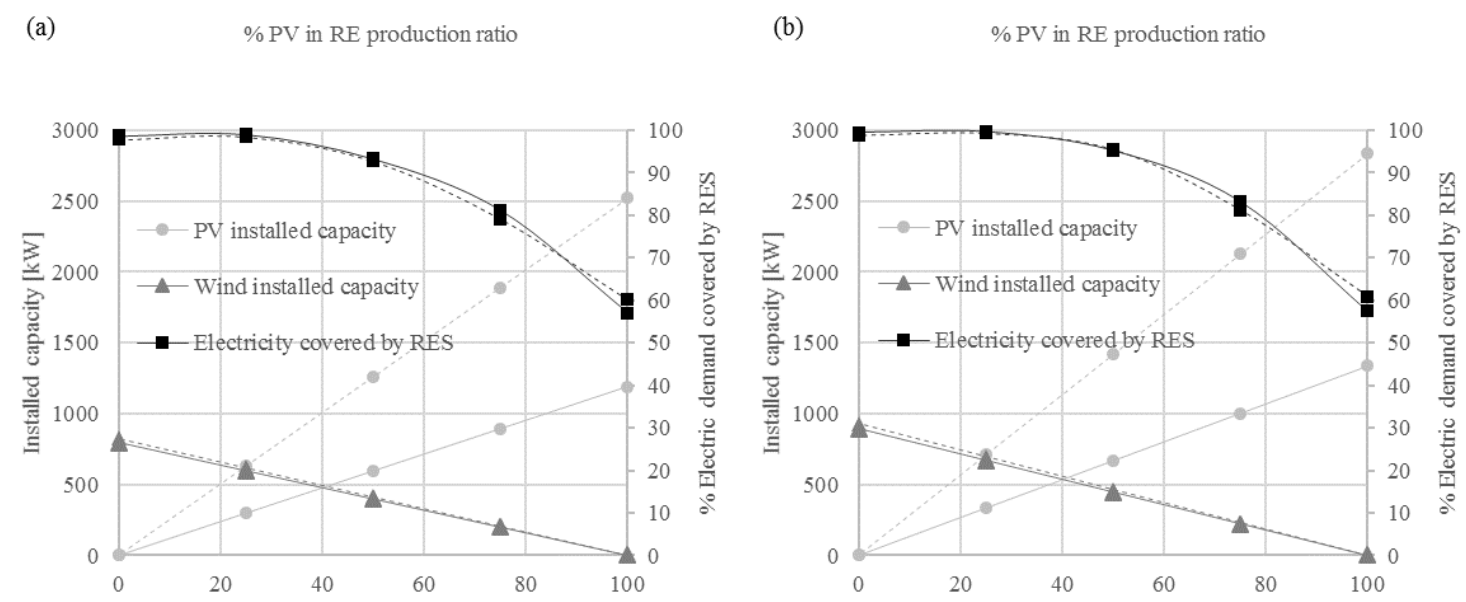

(c)

$\% \mathrm{PV}$ in $\mathrm{RE}$ production ratio

(d)

$\% \mathrm{PV}$ in $\mathrm{RE}$ production ratio

Fig. 7. PV and wind installed capacity and electric coverage by RES for different $E_{P V} / E_{R E S}:$ a) $E_{R E S} / E_{d}=1,5$; b) $E_{R E S} / E_{d}=1,75$; c) $E_{R E S} / E_{d}=2,0$; d) $E_{R E S} / E_{d}=2,25$. Full line represents South Europe results and Dotted line represents North Europe results.

\section{Thermal demand coverage}

The maximum thermal power demand of the studied sport facilities will be $192,5 \mathrm{~kW}$ in the South Europe location and 335,3 kW in the North Europe one. However, the production of synthetic natural gas which varies from 175 to $800 \mathrm{MWh}$ per year does not cover the total thermal demand of the sports facilities. Under this framework, the percentage of thermal demand covered by the RES-PtG-Oxyfuel boiler system strongly varies between 5\% and 90\% depending on the scenario (Fig. 9). 
A clear difference is observed between results obtained for North and South European studied cases. While the thermal demand coverage by means of the heat provided by the oxyfuel boiler ranges between approximately 10-20\% for most analysed situations of the South Europe sport facility, the coverage for the North European facility is much higher, between $30-70 \%$.
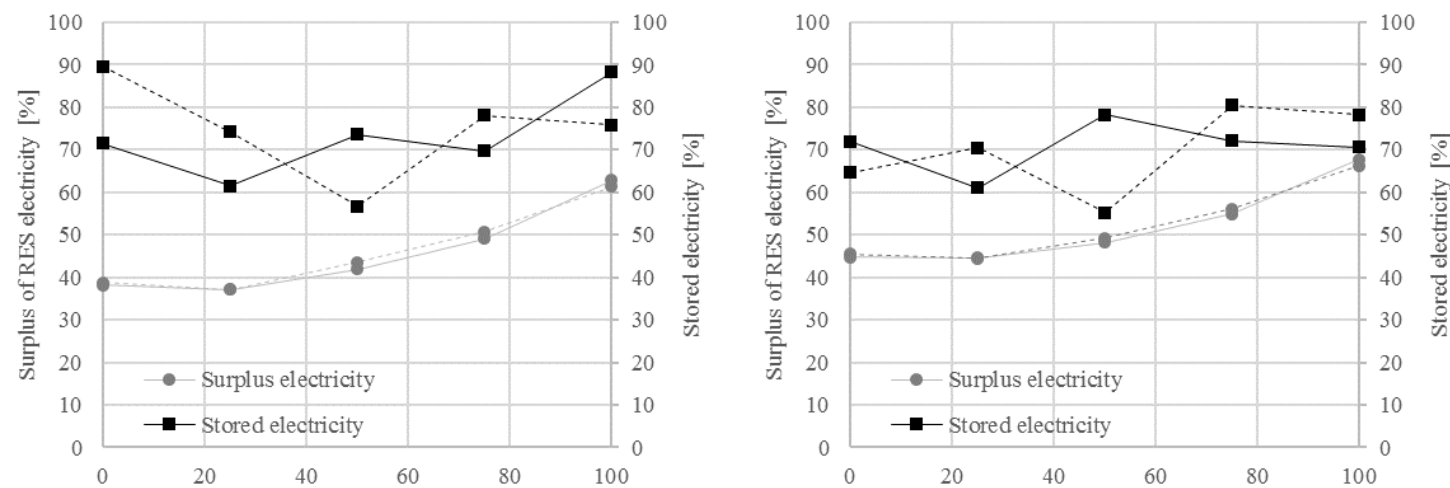

(a) $\% \mathrm{PV}$ in $\mathrm{RE}$ production ratio

(b)

$\% \mathrm{PV}$ in $\mathrm{RE}$ production ratio
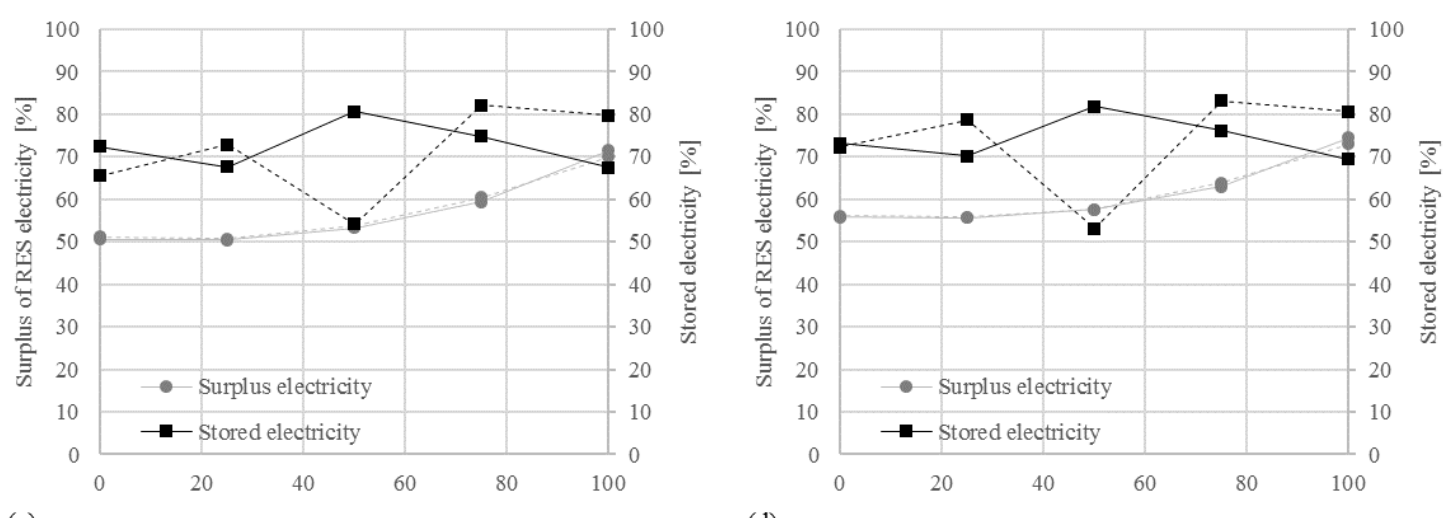

(d)

$\% \mathrm{PV}$ in $\mathrm{RE}$ production ratio

Fig. 8. Percentage of electricity surplus and stored electricity for different $\left.E_{P V} / E_{R E S}: a\right)$ $\left.\left.\left.E_{R E S} / E_{d}=1,5 ; b\right) E_{R E S} / E_{d}=1,75 ; c\right) E_{R E S} / E_{d}=2,0 ; d\right) E_{R E S} / E_{d}=2,25$.

The profiles of SNG production and thermal demand self-coverage are intimately associated and follow a similar trend when varying the combination of windphotovoltaic power in the system. $100 \%$ of photovoltaic power generation which present the largest storage potential will lead to the highest SNG production (up to 500 $\mathrm{MWh} / \mathrm{y}$ and $800 \mathrm{MWh} / \mathrm{y}$ for $\mathrm{SE}$ and $\mathrm{NE}$ cases respectively) and thermal demand coverage under these conditions could reach $78 \%$ and $90 \%$ for NE and SE cases respectively. 
As highlighted in the previous section, the amount of produced SNG is increased with the presence of photovoltaic power generation given its electricity production profile. This synthetic natural gas produced in the Power to Gas system will be directly consumed in the sport facilities under study or stored in the national natural gas grid depending on the instantaneous thermal demand of the facility. As presented in Figure 10, results obtained for the sport facility located in South Europe show the complete consumption of the produced SNG under most of the simulated scenarios. Thus, there is no room for SNG storage in the natural gas grid unless the total RES electricity produced highly surpasses the electricity demand of the sport centre (excess ratios of 2,0 and 2,25).
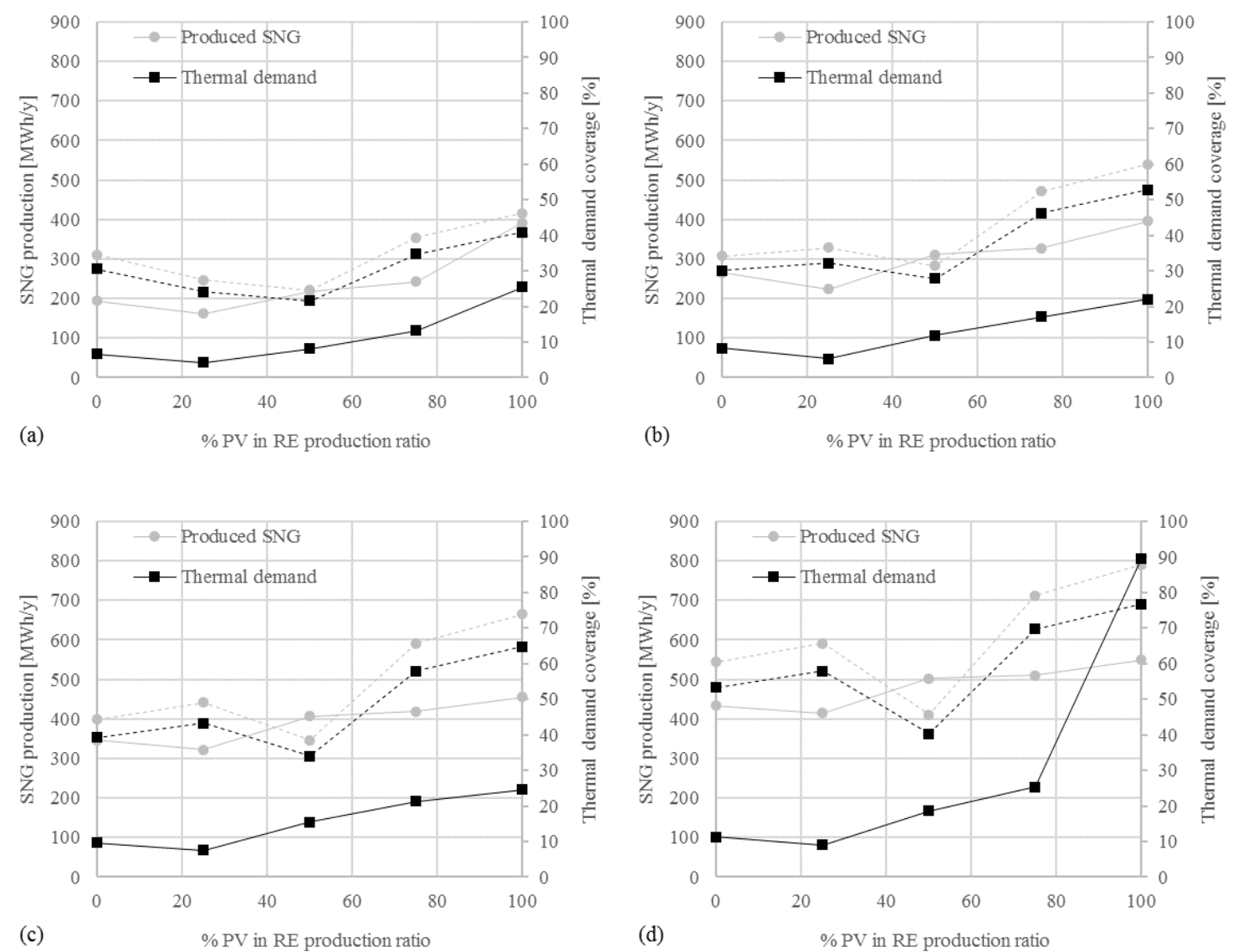

Fig. 9. Percentage of thermal demand coverage for different $E_{P V} / E_{R E S}:$ a) $E_{R E S} / E_{d}=1,5$; b) $E_{R E S} / E_{d}=1,75$; c) $E_{R E S} / E_{d}=2,0$; d) $E_{R E S} / E_{d}=2,25$.

The thermal demand distribution of the sport facility located in the North of Europe and the slightly higher amounts of produced SNG allows for storage under all the studied cases. Between $5-25 \%$ of the produced SNG could be stored in the grid for those cases 
which are most disadvantageous for storage. While for scenarios with high excess ratios and large shares of photovoltaic power, the stored SNG could reach the 35-65\% of the produced gas.

However, the amount of SNG which is instantaneously stored in the grid will be recovered between a 99-100\% under all the analysed scenarios. The amount of natural gas which will be purchased from the grid is illustrated in Figure 11. None of the analysed sport facilities can be thermally self-sufficient. There will be a dependence of the natural gas from the grid under every scenario which is reduced at high electricity excess ratios and for higher penetration of photovoltaic capacity in the RE mix installed in the sport facilities.

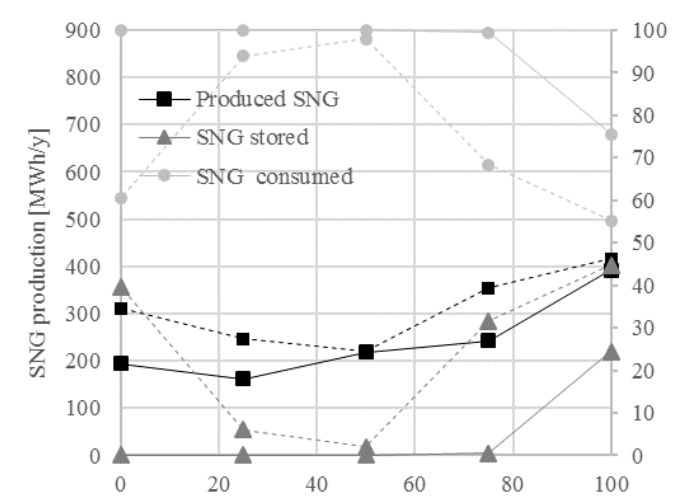

(a)

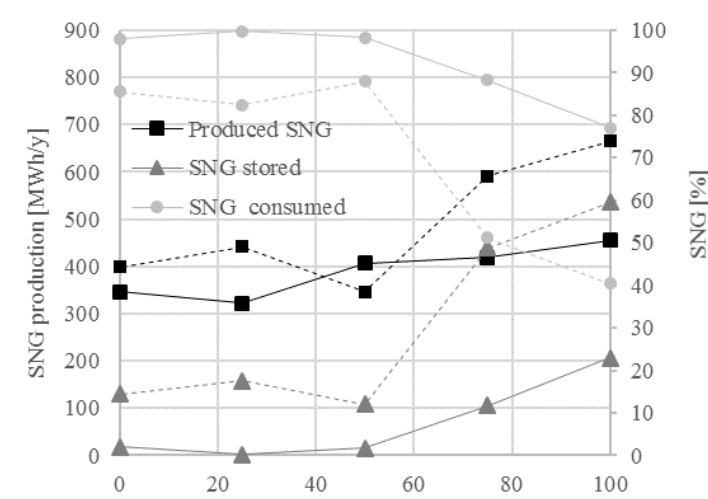

(c)

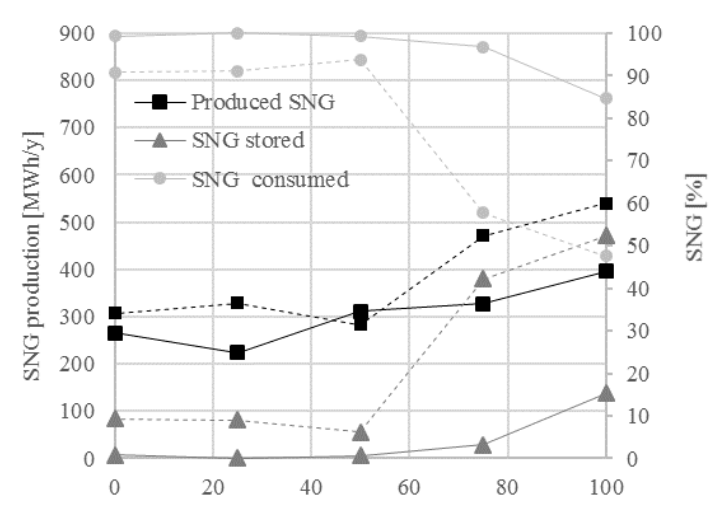

(b)

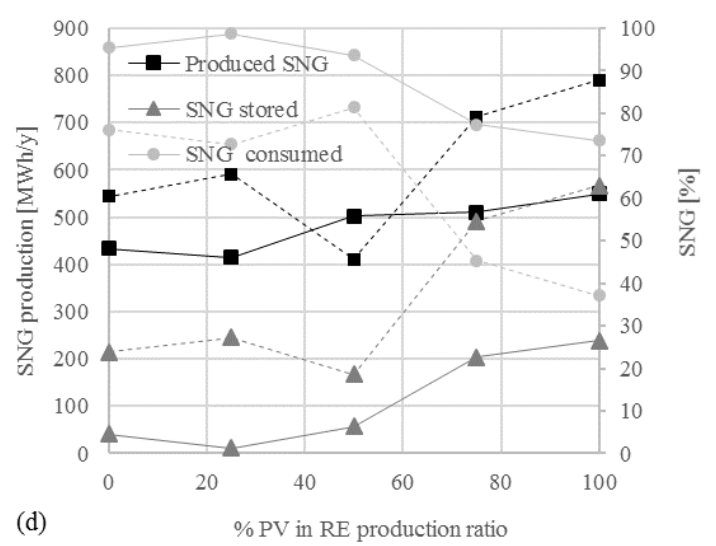

Fig. 10. Percentage of stored and consumed $S N G$ for different $E_{P V} / E_{R E S}:$ a) $E_{R E S} /$ $\left.\left.\left.E_{d}=1,5 ; b\right) E_{R E S} / E_{d}=1,75 ; c\right) E_{R E S} / E_{d}=2,0 ; d\right) E_{R E S} / E_{d}=2,25$.

\section{Temporal displacement of gas storage}

Other important aspect of these RES-PtG-Oxyfuel systems is the duration of the storage, i.e., for how long the stored surplus electricity is displaced. For the case study 
located in the South of Europe, the stored SNG is always consumed during the following 20 hours (Fig. $12(a)$ ). This short delay between surplus energy and thermal demand could be covered by other storage technologies with lower efficiency losses and less expensive (e.g., thermal storage in hot water deposits or batteries).

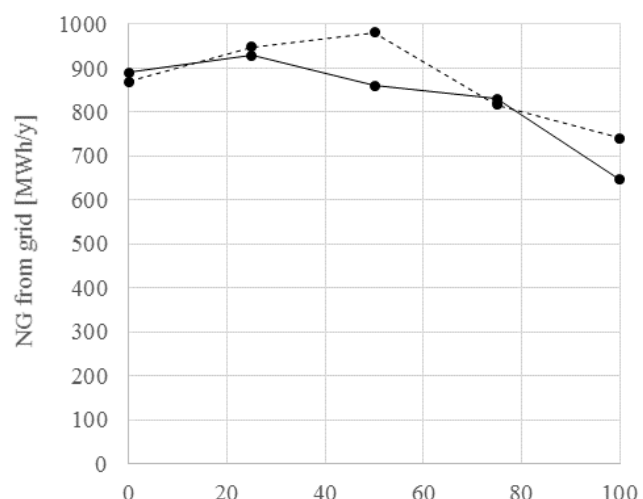

(a)

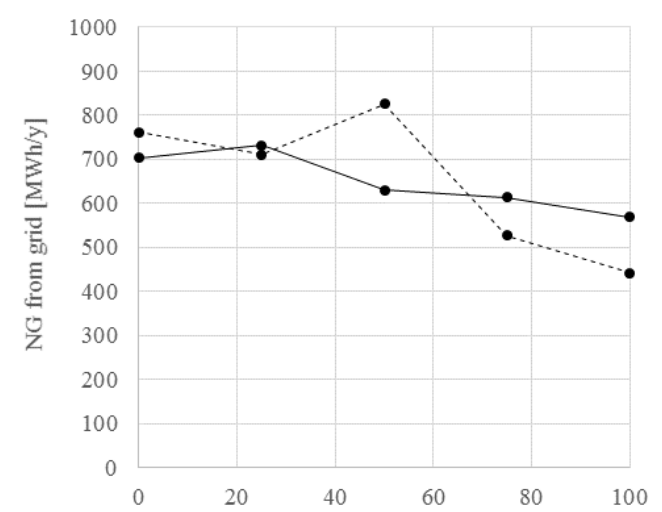

(c)
$\% \mathrm{PV}$ in $\mathrm{RE}$ production ratio

$\% \mathrm{PV}$ in $\mathrm{RE}$ production ratio

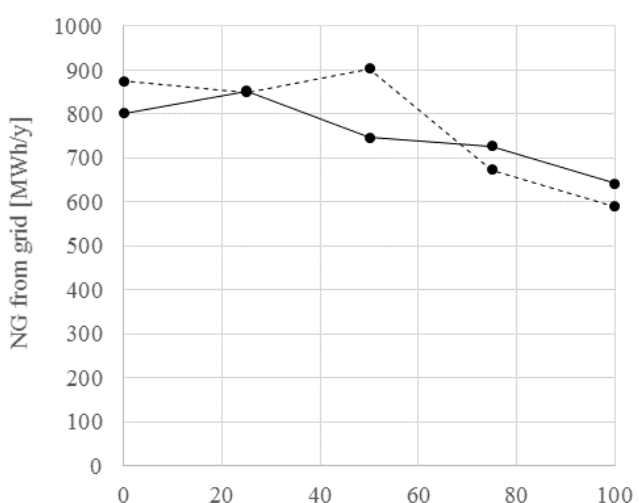

(b)

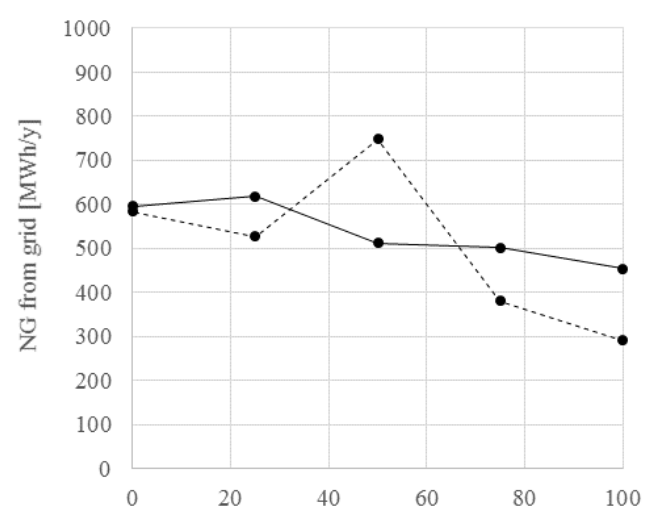

(d)

$\% \mathrm{PV}$ in $\mathrm{RE}$ production ratio

Fig. 11. Natural gas taken from the grid for different $E_{P V} / E_{R E S}:$ a) $\left.E_{R E S} / E_{d}=1,5 ; b\right)$

$$
\left.\left.E_{R E S} / E_{d}=1,75 ; c\right) E_{R E S} / E_{d}=2,0 ; d\right) E_{R E S} / E_{d}=2,25 \text {. }
$$

However, when North Europe location is analysed (Fig. $12(\mathrm{~b})$ ), the displacement is in the range of months. Thus, the utilization of Power to Gas technology would be better justified. The issue that arise is the requirement of pressurized storage of oxygen and carbon dioxide. Great amounts of $\mathrm{CO}_{2}$ must be consumed to produce more methane than the introduced into the boiler, while surplus $\mathrm{O}_{2}$ has to be stored. Conversely, the stored $\mathrm{O}_{2}$ will be consumed to operate the oxyfuel boiler since SNG is recovered from the network, and $\mathrm{CO}_{2}$ will be an excess. 


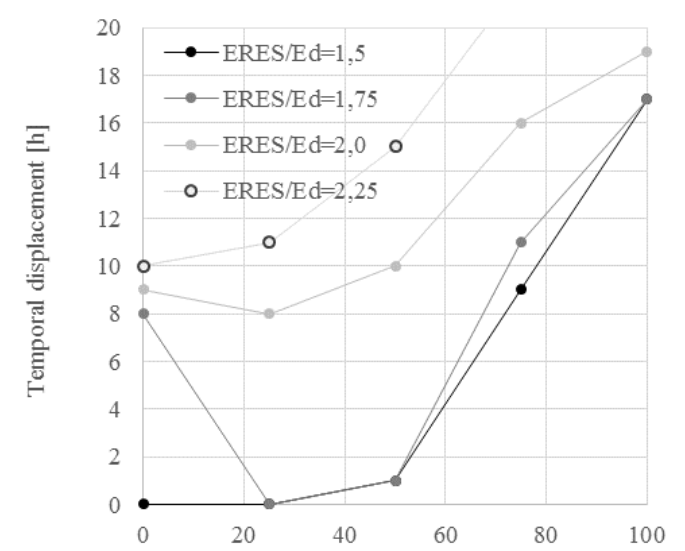

(a)

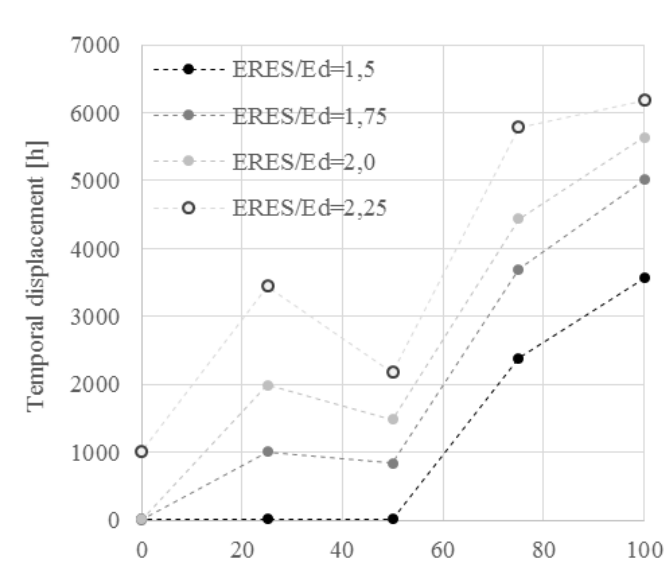

(b)

$\% \mathrm{PV}$ in $\mathrm{RE}$ production ratio

Fig. 12. Temporal displacement of produced $S N G$ usage for different $E_{P V} / E_{R E S}$ :

a) South Europe b) North Europe.

\section{Brief discussion on the economic feasibility of the integrated system}

Some comments regarding economics can be done attending to the results of the technical analysis, in which two scenarios stand out: (i) the scenario with the highest SNG production (i.e., $\mathrm{E}_{\mathrm{RES}} / \mathrm{E}_{\mathrm{d}}=2.25$ and $100 \% \mathrm{PV}$ ), and (ii) the scenario with the best self-coverage of electricity demand (i.e., $\mathrm{E}_{\mathrm{RES}} / \mathrm{E}_{\mathrm{d}}=2.25$ and $25 \% \mathrm{PV}-75 \%$ Wind). The latter prioritises the proper adjustment between the renewable electricity production and the electricity demand (coverage above the 99\%), what results in a renewable excess that only allows covering the $57.9 \%$ and $45.2 \%$ of thermal demand in the North and South regions, respectively. Whereas the former scenario maximizes the amount of SNG produced, and therefore the thermal demand's coverage rises to $76.8 \%$ and $59.8 \%$, respectively. However, this scenario would be better only if the savings from purchasing less natural gas are greater than the sum of the cost of purchasing the electricity that is not self-covered (39.1\% in North, and $42.5 \%$ in South) and the extra cost of amortisation coming from the greater electrolyser's size (543 kW instead of 153 $\mathrm{kW}$ in North, and $320 \mathrm{~kW}$ instead of $101 \mathrm{~kW}$, in South) and renewable power capacity (2835.8 kW instead of $1407.6 \mathrm{~kW}$ in North, and $1338.7 \mathrm{~kW}$ instead of $1004.5 \mathrm{~kW}$ in South) that are needed. Assuming a cost of $30 € / \mathrm{MWh}$ for the natural gas, the savings would be $7074 € / y$ in the North, and $4953 € / y$ in the South, what clearly will not cover the extra costs. Therefore, the self-coverage should be prioritised, instead of greater Power to Gas capacities. 
Moreover, even the scenario of best self-coverage is selected, the utilisation of Power to Gas as energy storage option may be not the ideal technology in some cases. In the South region, the longest displacement in time that is required is only 11 hours, what may be achieved with hot-water thermal storage or batteries (cheaper technology). The results in the North region do show a displacement in time above 3450 hours (144 days), what justifies the utilisation of Power to Gas technology against other cheaper technologies.

\section{Conclusions}

The application of PtG-Oxyfuel systems in non-residential buildings of the tertiary sector that have photovoltaic panels and urban wind turbines has been proposed and analysed. The surplus electricity coming from PV and wind is managed and stored through Power to Gas technology in the form of methane to be later used in an oxyfuel boiler and cover thermal demand. The study case has been focused in sports centres given their large roof surfaces and thermal consumptions.

Several scenarios have been proposed depending on the ratio between PV-Wind installed power and the annual RES electricity surplus of $50 \%, 75 \%, 100 \%$ or $125 \%$. It was found that the percentage of thermal demand covered by the RES-PtG-Oxyfuel system widely varies between 20 and $60 \%$ for Spain and 20 and $70 \%$ for Sweden. The systems dimensions (solar PV and wind power) should be larger in the North than in the South and varies depending on the PV-wind proportion. For a $0 \% \mathrm{PV}$ the wind power is around a 5\% higher in Sweden than in Spain, but with $100 \%$ PV power the systems should be a $110 \%$ higher. This forces to dimension larger electrolyser and methanizer and, consequently, less operational hours in the North of Europe. Nevertheless, the time displacement of the stored energy is much larger in the North (around months in several cases) than in the South that is only few hours. In this last case, economic comparisons with batteries and thermal storage technologies would determine the best option for surplus electricity management. Evidently, in the case of North Europe larger gases storage is needed to take advantage of the stored energy during the cold months.

It must be highlighted that this storage behaviour and energy long-term displacement observed in the Northern geographical location is strongly influenced by the thermal consumption pattern of the specific sport facility under analysis and it is not possible to state that other Northern sport facility will follow this storing pattern. 
The larger the proportion of wind energy the smaller installed power capacity of the overall system. It includes also the electrolyser and methanizer. As the operational hours are reduced, the storage capacity is also reduced and, consequently, the displacement of the stored energy. This result could be expected because it is associated to the different variability characteristics of solar and wind resources. The intrinsic daily and seasonal periodicity of solar generation produces maxima at midday and summer periods, coinciding with low energy demand. Wind resource follows less clear oscillations that are diluted when average values are considered. Accordingly to these generation patterns, PV power is more suitable than wind power to reach long energy storage periods in which PtG takes advantage over other conventional technologies, as batteries, oriented to short-term storage. However, it should be noted that the savings from the avoidance of purchasing natural gas will be normally not enough to justify the cost of installing further power capacity.

Finally, with larger installed power in comparison with power demand the size of the equipment increases and also the displacement of the stored energy.

\section{Acknowledgments}

The work described in this paper is supported by the $\mathrm{R}+\mathrm{D}$ Spanish National Program from Ministerio de Economía y Competitividad, MINECO (Spanish Ministry of Economy and Competitiveness) and the European Regional Development Funds (European Commission), under project ENE2016-76850-R. This work has also been supported by the Government of Aragon (Research Group DGA T46_17R) and cofinanced by FEDER 2014-2020 "Construyendo Europa desde Aragón".

\section{Nomenclature}

\begin{tabular}{|l|l|}
\hline ASU & Air separation unit \\
\hline $\mathrm{CH}_{4}$ & Methane / Methanation process \\
\hline $\mathrm{CO}_{2}$ & Carbon dioxide \\
\hline $\mathrm{E}$ & Energy \\
\hline $\mathrm{E}_{\mathrm{d}}$ & Electricity consumption \\
\hline EED & Energy Efficiency Directive \\
\hline EPDB & Energy Performance of Building Directive \\
\hline EPV $_{\mathrm{PV}}$ & Photovoltaic Energy \\
\hline $\mathrm{E}_{\mathrm{RES}}$ & Renewable Energy \\
\hline
\end{tabular}




\begin{tabular}{|l|l|}
\hline $\mathrm{H}_{2}$ & Hydrogen / Electrolysis process \\
\hline NE & North Europe \\
\hline NEEAPs & National Energy Efficiency Action Plans \\
\hline NZEBs & Nearly Zero Energy Buildings \\
\hline PtG & Power to Gas \\
\hline PV & Photovoltaic solar panels \\
\hline RE & Renewable energy \\
\hline RES & Renewable energy sources \\
\hline SE & South Europe \\
\hline SNG & Synthetic Natural Gas \\
\hline
\end{tabular}

\section{References}

[1] Eurostat. Eurostat statistics explained - Consumption of energy 2017.

[2] Bertoldi P, Lopez Lorente J, Labanca N. Energy Consumption and Energy Efficiency Trends in the EU-28 (2000-2014). 2016. doi:10.2788/581574.

[3] European Parliament. Directive 2012/27/EU of European Parliament and of the Council of 25 October 2012 Energy on Efficiency, Amending Directives 2009/125/EC and 2010/30/EU and Repealing Directives 2004/8/EC and 2006/32/EC. Off J Eur Union 2012;4:202-257.

[4] European Parliament. Directive 2010/31/EU of the European parliament and of the council of 19 May 2010 on the energy performance of buildings. Off J Eur Union 2010;3:124-146.

[5] Lu Y, Wang S, Shan K. Design optimization and optimal control of gridconnected and standalone nearly/net zero energy buildings. Appl Energy 2015;155:463-477.

[6] Renewable Energy Policy Network. Renewables 2016 Global Status Report. 2016.

[7] International Energy Agency. Technology Roadmap - Solar Photovoltaic Energy. Paris, France: 2014.

[8] WindEurope. Wind in power 2017. Annual combined onshore and offshore wind energy statistics. 2018.

[9] WindEurope. Wind energy in Europe: Scenarios for 2030. 2017. 
[10] Mahesh A, Sandhu KS. Hybrid wind/photovoltaic energy system developments: Critical review and findings. Renew Sustain Energy Rev 2015;52:1135-47. doi:10.1016/J.RSER.2015.08.008.

[11] Abdon A, Zhang X, Parra D, Patel MK, Bauer C, Worlitschek J. Technoeconomic and environmental assessment of stationary electricity storage technologies for different time scales. Energy 2017;139:1173-87. doi:10.1016/J.ENERGY.2017.07.097.

[12] Ibrahim H, Ilinca A, Perron J, Ibrahim H, Ilinca A, Perron J. Renewable \&amp; sustainable energy reviews. vol. 12. Elsevier Science; 1997.

[13] Tronchin L, Manfren M, Nastasi B. Energy efficiency, demand side management and energy storage technologies - A critical analysis of possible paths of integration in the built environment. Renew Sustain Energy Rev 2018;95:341-53. doi:10.1016/J.RSER.2018.06.060.

[14] Blanco H, Faaij A. A review at the role of storage in energy systems with a focus on Power to Gas and long-term storage. Renew Sustain Energy Rev 2018;81:1049-86. doi:10.1016/j.rser.2017.07.062.

[15] Nastasi B, Lo Basso G. Hydrogen to link heat and electricity in the transition towards future Smart Energy Systems. Energy 2016;110:5-22. doi:10.1016/J.ENERGY.2016.03.097.

[16] Bailera M, Lisbona P, Romeo LM, Espatolero S. Power to Gas projects review: $\mathrm{Lab}$, pilot and demo plants for storing renewable energy and $\mathrm{CO} 2$. Renew Sustain Energy Rev 2017;69:292-312. doi:10.1016/j.rser.2016.11.130.

[17] Vo TTQ, Xia A, Wall DM, Murphy JD. Use of surplus wind electricity in Ireland to produce compressed renewable gaseous transport fuel through biological power to gas systems. Renew Energy 2017;105:495-504. doi:10.1016/J.RENENE.2016.12.084.

[18] Streibel M, Nakaten N. Analysis of an Integrated Carbon Cycle for Storage of Renewables. $\quad$ Energy 2013;40:202-11. doi:10.1016/J.EGYPRO.2013.08.024.

[19] Qadrdan M, Abeysekera M, Chaudry M, Wu J, Jenkins N. Role of power-to-gas in an integrated gas and electricity system in Great Britain. Int J Hydrogen Energy 2015;40:5763-75. doi:10.1016/J.IJHYDENE.2015.03.004. 
[20] Rönsch S, Schneider J, Matthischke S, Schlüter M, Götz M, Lefebvre J, et al. Review on methanation - From fundamentals to current projects. Fuel 2016;166:276-96. doi:10.1016/J.FUEL.2015.10.111.

[21] Estermann T, Newborough M, Sterner M. Power-to-gas systems for absorbing excess solar power in electricity distribution networks. Int J Hydrogen Energy 2016;41:13950-9. doi:10.1016/J.IJHYDENE.2016.05.278.

[22] Parra D, Swierczynski M, Stroe DI, Norman SA, Abdon A, Worlitschek J, et al. An interdisciplinary review of energy storage for communities: Challenges and perspectives. Renew Sustain Energy Rev 2017;79:730-49. doi:10.1016/J.RSER.2017.05.003.

[23] Jarnut M, Wermiński S, Waśkowicz B. Comparative analysis of selected energy storage technologies for prosumer-owned microgrids. Renew Sustain Energy Rev 2017;74:925-37. doi:10.1016/J.RSER.2017.02.084.

[24] O'Shea R, Wall DM, McDonagh S, Murphy JD. The potential of power to gas to provide green gas utilising existing $\mathrm{CO} 2$ sources from industries, distilleries and wastewater treatment facilities. Renew Energy 2017;114:1090-100. doi:10.1016/J.RENENE.2017.07.097.

[25] International Energy Agency IEA. Technology Roadmap Energy storage. n.d.

[26] Bailera M, Lisbona P, Romeo LM. Power to gas-oxyfuel boiler hybrid systems. Int J Hydrogen Energy 2015;40. doi:10.1016/j.ijhydene.2015.06.074.

[27] Bailera M, Lisbona P, Romeo LM, Espatolero S. Power to Gas-biomass oxycombustion hybrid system: Energy integration and potential applications. Appl Energy 2016;167:221-9. doi:10.1016/j.apenergy.2015.10.014.

[28] Bailera M, Kezibri N, Romeo LM, Espatolero S, Lisbona P, Bouallou C. Future applications of hydrogen production and $\mathrm{CO} 2$ utilization for energy storage: Hybrid Power to Gas-Oxycombustion power plants. Int J Hydrogen Energy 2017;42. doi:10.1016/j.ijhydene.2017.02.123.

[29] Bailera M, Espatolero S, Lisbona P, Romeo LM. Power to gas-electrochemical industry hybrid systems: A case study. Appl Energy 2017;202:435-46. doi:10.1016/j.apenergy.2017.05.177.

[30] European Commission. PVGIS - Photovoltaic geographical information system 2018. 
[31] Red Eléctrica de España. Red Eléctrica de España. Power generation in the peninsula. 2018. https://demanda.ree.es/movil/peninsula/demanda/tablas/201701-01/2 (accessed December 17, 2018).

[32] Mimer. Mimer. Production statistics for Sweden in 2017 (Produktionsstatistik, vindkraftproduktion, Hela Sverige). Produktionsstatistik, Vindkraftproduktion, Hela Sverige 2018. https://mimer.svk.se/ProductionConsumption/ProductionIndex (accessed December 17, 2018).

[33] Ducar IA. Study on Energy Efficiency and Energy Saving Potential in San Agustin Sports Centre. 2017.

[34] Bailera M, Peña B, Llera E, Lisbona P RL. Renewable energy and Power-to-gas aided cogeneration for residential uses. Proc. ECOS 2018 - 31st Int. Conf. Effic. cost, Optim. Simul. Environ. impact energy Syst., June 17-22, 2018, Guimaraes, Portugal: 2018.

[35] Berdenius M TI. Energikartläggning av idrottsanläggningar (Energy survey of sports facilities). Final degree project at the Degree of Civil Engineering (in Swedish). University of Lund, 2015.

[36] Píriz AG. Auditoría energética en una piscina climatizada. 2009.

[37] Bailera M, Peña B, Lisbona P, Romeo LM. Decision-making methodology for managing photovoltaic surplus electricity through Power to Gas: Combined heat and power in urban buildings. Appl Energy 2018;228. doi:10.1016/j.apenergy.2018.06.128.

[38] Götz M, Lefebvre J, Mörs F, McDaniel Koch A, Graf F, Bajohr S, et al. Renewable Power-to-Gas: A technological and economic review. Renew Energy 2016;85:1371-90. doi:10.1016/j.renene.2015.07.066.

[39] Koponen J, Kosonen A, Huoman K, Ahola J, Ahonen T, Ruuskanen V. Specific energy consumption of PEM water electrolysers in atmospheric and pressurised conditions. 2016 18th Eur. Conf. Power Electron. Appl. (EPE'16 ECCE Eur., IEEE; 2016, p. 1-10. doi:10.1109/EPE.2016.7695576.

[40] Bailera M, Lisbona P, Romeo LM. Power to gas-oxyfuel boiler hybrid systems. Int J Hydrogen Energy 2015;40:10168-75. doi:10.1016/j.ijhydene.2015.06.074.

[41] $\mathrm{Hu}$ Y, Li X, Li H, Yan J. Peak and off-peak operations of the air separation unit 
in oxy-coal combustion power generation systems. Appl Energy 2013;112:74754. doi:10.1016/J.APENERGY.2012.12.001. 